\title{
ANALYSIS AND EVALUATION OF COMFORT OF HOUSING COMPLEXES (DEVELOPMENT STUDIES IN WESTERN UKRAINE)
}

\author{
Smadych I.P., PhD, Associate Professor, \\ Architectvan@gmail.com, ORCID: 0000-0001-7964-5730 \\ Ivano-Frankivsk National Technical University Oil and Gas,
} 15, Karpatska street, Ivano-Frankivsk, 76019, Ukraine

\begin{abstract}
Architects and urban planners in the process of designing residential areas use building codes that consider the comfort of living only in terms of safety, sanitation and environmental performance. This article highlights the problem of taking into account a number of additional social parameters of comfort that affect the characteristics of living comfort. The structure of a comprehensive analysis of housing is formed by assessing the elements of living comfort. The presented research algorithm includes the consistent use of methods of sociological survey, evaluation and modeling. Having identified socio-psychological factors of comfort of a residential district at different levels of urban assessment (in the context of location in the city system, formation of the surrounding area, spatial and architectural-planning level), 3 residential development projects of IvanoFrankivsk were assessed. For a comparative analysis, the architectural and planning solutions of residential quarters "Lemkivsky", "Club town 12", "Vidensky" were used, the construction of which began in 2017.
\end{abstract}

This took into account not only the quantitative technical and economic indicators of individual elements of the project, but also qualitative indicators, the measurement of which in normal conditions is a resource-intensive process. As a result of the analysis and the carried-out estimation the graphic model of the complex analysis of a residential quarter is formed that allows to carry out comparison of various design decisions irrespective of size of a site of quantity of housing sections, etc. Using the method of movement to the ideal, a comprehensive analysis of various residential complexes was carried out. The obtained results allow, both at the stage of designing residential neighborhoods and the analysis of operated facilities to assess them in accordance with the needs of people, as well as to balance the indicators of comfort by applying the proposed architectural and planning techniques.

Keywords: residential architecture, sociopsychological comfort of multi-storey residential complexes, assessment of sociopsychological comfort, method of movement to the ideal.

Introduction. Comfort is the level of integration and coordination of socio-psychological aspects of the individual in the multidimensional space of his stay [8]. In the human-centric society of the XXI century, the concepts of satisfaction of needs and feelings of comfort are the primary features that must be taken into account when creating a living environment. In the process of designing residential complexes, the architect must take into account a number of parameters relating to safety, socio-economic, sanitary and hygienic aspects of human life. People in the living environment are considered only as a socio-economic unit [12] without taking into account its needs and the peculiarities of changing life in the modern world. In Ivano-Frankivsk, which has a high rate of construction of residential real estate in Ukraine, there are problems of standardization and typification of housing as a mass product. The purpose of this study is to find ways to take into account the social aspects of living comfort of the population of a particular city in the analysis and evaluation of residential complexes. The object of study are the characteristics of the comfort of multi-storey residential complexes.

In accordance with the purpose of this study, the following hypotheses were formed:

- the structure of socio-mental human needs related to the comfort of housing estates are invested in the overall stratification of human needs regardless of the scale of the study (the whole system or a separate element of the housing complex); 
- the possibility of applying the algorithm of analysis and evaluation of residential complexes have universal application and can be applied to different types of residential buildings;

- at the stage of creating design solutions you can take into account the socio-mental needs of man and create a residential complex, in accordance with the conditions of comfort for the inhabitants of the area.

Scientific basis of this study. The interdisciplinary nature of the problem, on the solution of which this research is focused, has formed the need to analyse scientific works on architecture, urban planning, architectural sociology, psychology, economics and others. The main research methods are the method of sociological survey, which with a high level of objectivity demonstrates the hierarchy of needs of the population when choosing housing. At the stage of assessing the characteristics of residential complexes, the method of distance to the ideal was applied [7]. This evaluation method involves comparing a set of established criteria with an idealized variant (standard) and determines a numerical indicator that is actually an integral criterion for evaluating the object, combining all the criteria by which the comparison takes place. The ideal option for assessing the characteristics of residential complexes is the conditional option with the highest rates for each of the 4 levels of assessment.

The graphical image of this method is presented on a set of 4 groups of criteria (vectors), and all of them improve from the centre (conditional starting point from 0 indicator). The best variant according to this method is the one for which the area of the polygon constructed on the evaluation field is the closest to the idealized variant with the highest evaluations. The versatility of this method is proved by a wide range of applications in the areas of assessment of recreational, historical and cultural, residential buildings and urban complexes. Some aspects of this study are formed based on scientific work in the field of architectural sociology [23, 24], studies of the impact of sociopsychological and socio-mental aspects of human life on housing architecture [18, 22]. Methods of analysis and evaluation of multi-storey residential buildings in scientific works $[1,27]$ contributed to the formation of multilevel.

Research of human social needs in the context of housing choice. In the context of the large supply of housing in the market of Ivano-Frankivsk, each consumer seeks and constantly compares different types of housing complexes on many grounds that best meet his needs. The set of individual needs of each person is quite diverse, but there are a number of common features that are common to most people, due to common features of social behavior and life rhythm (work, family, time-rest, spiritual and social beliefs, culture, habits, traditions etc.) $[10,20]$. It is the analysis of scientific works in the field of architectural sociology [6] and changes in the living environment of cities $[3,11,16]$ allowed to form scientific approaches to analysis and assessment of living comfort in residential complexes depending on the architectural-spatial and planning indicators of the object. For the initial assessment of human needs, a survey of 25 respondents who bought housing in Ivano-Frankivsk in 2020 was conducted [21]. For further processing and analysis of the results of the survey, all needs are stratified according to the levels of characteristics of the architectural object [13]:

- accommodation in an urban environment;

- infrastructure of yard territories;

- three-dimensional solutions;

- architectural and planning decisions.

At the level of location in the urban environment, some indicators can be distinguished from the normative linear distances from the residential complex to the infrastructure. However, in the aggregate assessment of the main parameters of the location of any architectural object in the urban space can form an "index of accommodation conditions" as a comprehensive indicator of the assessment of the choice of site for design.

Interpreting the general list of human needs [21] in the context of the study of housing estates, the open type of questionnaire with the ability to add answer options and evaluate the available options has significantly improved the quality of the sample. The needs assessment scale was 0-10 [17]. Summary results of the survey (Table 1) are presented in a hierarchical sequence by the sum of the assessment each of the options by all respondents. 
Table 1 - Evaluation of human needs when choosing a residential complex

\begin{tabular}{|c|c|c|c|}
\hline Common name of the need & Indexes & Parameters & Rating \\
\hline \multicolumn{4}{|c|}{ Location in an urban environment } \\
\hline $\begin{array}{l}\text { Ecological indicators of the } \\
\text { construction territory }\end{array}$ & Pollution index & & 163 \\
\hline $\begin{array}{l}\text { Availability of good transport } \\
\text { links }\end{array}$ & & $\begin{array}{l}\text { Index of } \\
\text { accommodation } \\
\text { conditions }\end{array}$ & 160 \\
\hline $\begin{array}{l}\text { The presence of a recreational } \\
\text { area nearby }\end{array}$ & & $\begin{array}{l}\text { Index of } \\
\text { accommodation } \\
\text { conditions } \\
\end{array}$ & 156 \\
\hline Good view from the window & & $\begin{array}{l}\text { Index of } \\
\text { accommodation } \\
\text { conditions } \\
\end{array}$ & 154 \\
\hline $\begin{array}{l}\text { Availability of public transport } \\
\text { stops near the house }\end{array}$ & $\begin{array}{l}\text { Public transport stop } \\
\text { coverage radius (up to 150m) }\end{array}$ & $\begin{array}{l}\text { Index of } \\
\text { accommodation } \\
\text { conditions }\end{array}$ & 147 \\
\hline $\begin{array}{l}\text { Availability of social } \\
\text { infrastructure nearby (shops, } \\
\text { hairdressers, pharmacies, etc.) }\end{array}$ & (up to $500 \mathrm{~m}$ ) & $\begin{array}{l}\text { Index of } \\
\text { accommodation } \\
\text { conditions } \\
\end{array}$ & 136 \\
\hline $\begin{array}{l}\text { Accessibility to educational } \\
\text { institutions }\end{array}$ & $\begin{array}{l}\text { Radius of coverage of } \\
\text { educational institutions }\end{array}$ & & 105 \\
\hline \multicolumn{4}{|c|}{ Infrastructure of the inter-house and indoor territory } \\
\hline Quality of landscaping & & $\begin{array}{l}\text { The level of } \\
\text { improvement of } \\
\text { residential } \\
\text { construction }\end{array}$ & 137 \\
\hline $\begin{array}{l}\text { Qualitative work of public } \\
\text { utilities on the territory of } \\
\text { building (timely cleaning, } \\
\text { garbage removal) }\end{array}$ & & $\begin{array}{l}\text { The level of } \\
\text { improvement of } \\
\text { residential } \\
\text { construction }\end{array}$ & 134 \\
\hline $\begin{array}{l}\text { The level of security of the } \\
\text { courtyard }\end{array}$ & $\begin{array}{l}\text { The level of security of the } \\
\text { residential construction }\end{array}$ & & 127 \\
\hline $\begin{array}{l}\text { Comfortable and sufficient } \\
\text { number of residents }\end{array}$ & $\begin{array}{l}\text { Population density (up to } 450 \\
\text { people/ha) }\end{array}$ & & 126 \\
\hline $\begin{array}{l}\text { Comfort of living } \\
\text { accommodation and additional } \\
\text { infrastructure }\end{array}$ & $\begin{array}{l}\text { Provided housing (from } 12 \\
\mathrm{~m}^{2} / \text { person) }\end{array}$ & & \\
\hline $\begin{array}{l}\text { The presence of a high level of } \\
\text { greening of courtyards }\end{array}$ & $\begin{array}{l}\text { Level of greening of the } \\
\text { residential quarter (from } 40 \% \\
\text { of the building area) }\end{array}$ & & 123 \\
\hline $\begin{array}{l}\text { Availability of attractive } \\
\text { courtyard spaces for different } \\
\text { age groups of population }\end{array}$ & & $\begin{array}{l}\text { Functional zoning of } \\
\text { the adjacent territory }\end{array}$ & 109 \\
\hline Large areas of courtyards & From $65 \%$ of the total area & & 108 \\
\hline Provision of parking spaces & $\begin{array}{l}\text { Number of parking spaces in } \\
\text { the yard }\end{array}$ & & 104 \\
\hline $\begin{array}{l}\text { Use of expensive equipment } \\
\text { and materials for the } \\
\text { organization of courtyards }\end{array}$ & $\begin{array}{l}\text { Total costs for the } \\
\text { organization of quality } \\
\text { infrastructure of the adjacent } \\
\text { territory }\end{array}$ & & 95 \\
\hline
\end{tabular}


Continuation of Table 1

\begin{tabular}{|c|c|c|c|}
\hline \multicolumn{4}{|c|}{ Spatial planning solutions for multi-story residential buildings } \\
\hline Quality of construction & $\begin{array}{l}\text { Quality indicator of } \\
\text { construction works }\end{array}$ & & 184 \\
\hline $\begin{array}{l}\text { High energy efficiency rates of } \\
\text { housing }\end{array}$ & $\begin{array}{l}\text { Energy efficiency of a } \\
\text { residential building }\end{array}$ & & 171 \\
\hline The price of the apartment & $\begin{array}{l}\text { Apartment rental price } \\
\text { (UAH/month) / apartment } \\
\text { price (thousand UAH) }\end{array}$ & & 159 \\
\hline $\begin{array}{l}\text { An interesting architectural } \\
\text { solution of the building }\end{array}$ & & $\begin{array}{l}\text { The level of } \\
\text { harmony of the } \\
\text { three-dimensional } \\
\text { image of the } \\
\text { building }\end{array}$ & 151 \\
\hline $\begin{array}{l}\text { Ensuring free access of low- } \\
\text { mobility groups to the } \\
\text { apartments of a residential } \\
\text { building }\end{array}$ & & $\begin{array}{l}\text { Level of } \\
\text { accessibility for all } \\
\text { groups of the } \\
\text { population }\end{array}$ & 145 \\
\hline Number of floors & & $\begin{array}{l}\text { Floors of the } \\
\text { building }\end{array}$ & 137 \\
\hline $\begin{array}{l}\text { The quality of finishing } \\
\text { materials of the facade of } \\
\text { residential buildings }\end{array}$ & $\begin{array}{l}\text { Quality indicator of } \\
\text { construction works }\end{array}$ & & 134 \\
\hline $\begin{array}{l}\text { Harmony of a combination of } \\
\text { the colour decision of facades }\end{array}$ & & $\begin{array}{l}\text { The level of } \\
\text { harmony of the } \\
\text { three-dimensional } \\
\text { image of the } \\
\text { building }\end{array}$ & 127 \\
\hline $\begin{array}{l}\text { Harmonious organization of the } \\
\text { boundaries of the facades and } \\
\text { the yard }\end{array}$ & & Visual appeal & 120 \\
\hline $\begin{array}{l}\text { Status of the residential quarter } \\
\text { of the residential area }\end{array}$ & & $\begin{array}{l}\text { The image level of } \\
\text { the residential area }\end{array}$ & 111 \\
\hline \multicolumn{4}{|c|}{ Architectural and planning decisions of apartment houses } \\
\hline $\begin{array}{l}\text { Convenient solution for } \\
\text { engineering communications } \\
\text { in residential apartments }\end{array}$ & & $\begin{array}{l}\text { The level of } \\
\text { convenience of } \\
\text { laying engineering } \\
\text { networks for } \\
\text { apartment owners }\end{array}$ & 201 \\
\hline $\begin{array}{l}\text { High level of noise isolation of } \\
\text { apartments }\end{array}$ & Noise isolation level & & 195 \\
\hline $\begin{array}{l}\text { Use of quality materials and } \\
\text { equipment (elevators) }\end{array}$ & $\begin{array}{l}\text { The cost of housing } \\
\text { equipment }\end{array}$ & & 195 \\
\hline $\begin{array}{l}\text { Spacious planning of } \\
\text { apartments }\end{array}$ & & $\begin{array}{l}\text { The comfort level } \\
\text { of the apartment }\end{array}$ & 180 \\
\hline $\begin{array}{l}\text { Good insolation of the } \\
\text { apartment }\end{array}$ & $\begin{array}{l}\text { Insolation level (from } 4.5 \\
\text { hours for each apartment) }\end{array}$ & & 168 \\
\hline Good neighborhood & & $\begin{array}{l}\text { The level of image } \\
\text { of the residential } \\
\text { area }\end{array}$ & 161 \\
\hline
\end{tabular}


Continuation of Table 1

\begin{tabular}{|l|l|l|l|}
\hline $\begin{array}{l}\text { Availability of premises / } \\
\text { garages for car / bicycle } \\
\text { storage, }\end{array}$ & $\begin{array}{l}\text { Area of auxiliary premises of } \\
\text { a residential building (not } \\
\text { standardized) / ratio of the } \\
\text { number of parking spaces to } \\
\text { the number of residents of } \\
\text { residential buildings (0.8 cars } \\
\text { per apartment) }\end{array}$ & 149 \\
\hline $\begin{array}{l}\text { Possibility of redevelopment of } \\
\text { residential apartments }\end{array}$ & $\begin{array}{l}\text { The level of } \\
\text { adaptability of the } \\
\text { apartment }\end{array}$ & 148 \\
\hline $\begin{array}{l}\text { Convenient planning of access } \\
\text { to the apartment in the system } \\
\text { of a separate section }\end{array}$ & $\begin{array}{l}\text { The level of } \\
\text { convenience of the } \\
\text { planning scheme of } \\
\text { a residential } \\
\text { building }\end{array}$ & 145 \\
\hline $\begin{array}{l}\text { Availability of areas on the roof } \\
\text { of the house / stairwell for } \\
\text { communication between } \\
\text { residents }\end{array}$ & Space of common area use & & 120 \\
\hline
\end{tabular}

The human needs for housing presented in this questionnaire reproduce a slice of human needs in a specific period of time for the city of Ivano-Frankivsk. However, the general algorithm of this survey can be reproduced for residents of any locality.

Analysis of the results of respondents' answers at all levels of architectural and spatial analysis of architectural objects reproduces the general hierarchy of human needs A. Maslow [14] (Fig. 1), which confirms the high degree of probability of the results. The main needs of people when choosing housing are security needs (quality of construction work, reliability, etc.)

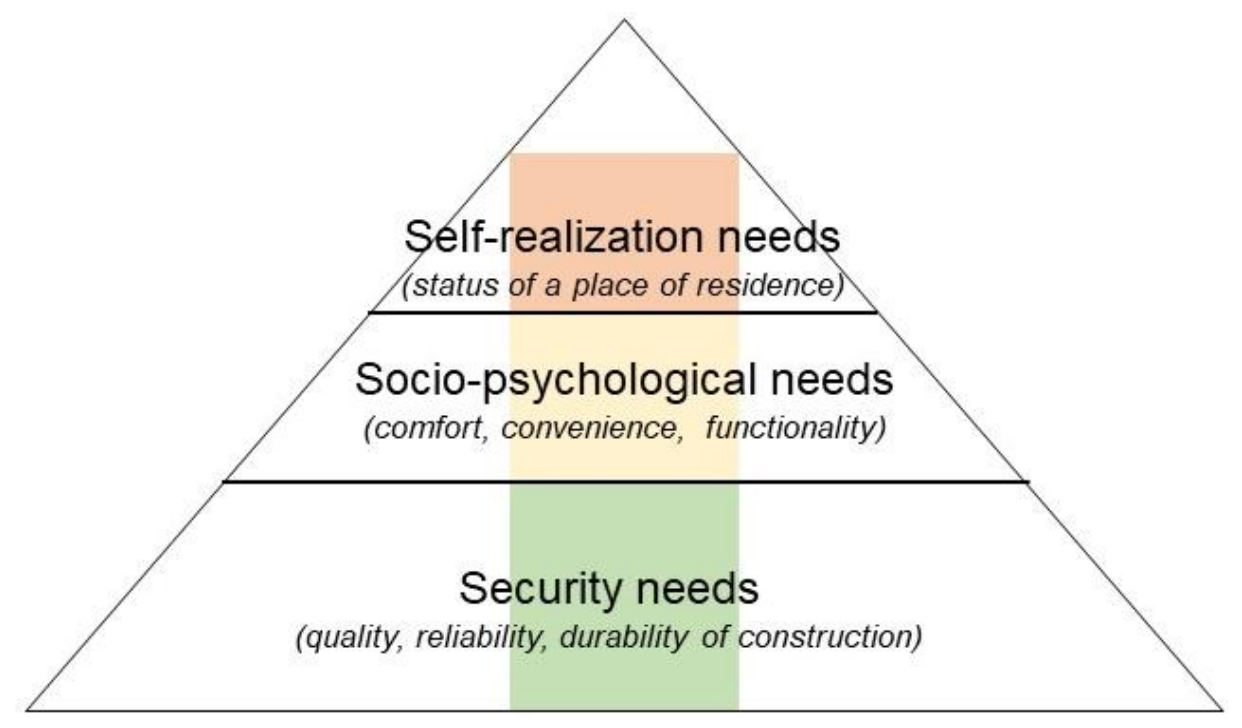

Fig. 1. The structure of human needs when choosing housing [5, 14]

The second group of sampling results covers a range of needs for comfort, functionality and cosiness, which are put forward to housing and represent the social, mental and psychological aspects of human life. The 3rd group of the sample consists of the needs of self-realization (status of the place of residence, provision additional elements of safety and comfort). 
This gradation shows that in addition to the socio-economic levers of housing choice (apartment price, installment terms) there are a number of socio-psychological and socio-mental needs that a person seeks to meet by buying a home. In contrast to the safety needs regulated by regulations in the field of construction and architecture, the socio-mental characteristics of comfort are only partially reflected in the regulatory and methodological framework of design.

Comparative analysis and evaluation of residential complexes. Table 1 , in addition to the direct gradation of human needs for housing, highlights the indicators and parameters by which you can conduct an initial assessment of human needs (comfort level) of the housing complex. Comprehensive analysis of the architectural object involves the assessment of the comfort of the residential complex in the analysis of the architectural documentation of the object.

The system of quantitative indicators of assessment, which reflect the linear features (distance, radius of coverage), features of comparison (provision of parking spaces in the garage, housing, etc.) is regulated by regulations in the field of construction and architecture. However, in addition to quantitative indicators, there is a group of qualitative ones (comfortable level of storeys of the house, interesting architectural and spatial solution of the residential complex, level of convenience), which are difficult to assess by analyzing project documentation $[9,26]$. M. Vilenskii in his research pointed to the method of expert evaluations as one of the most effective methods of analysis and evaluation of quantitative and qualitative indicators that characterize the object [25].

The empirical part of the study is based on the analysis and evaluation of project documentation of 3 multi-storey residential complexes ("Klubne Mistechko 12" on Promyslova Street, "Kvartal Videnskyi" on Mazepy Street, "Kvartal Lemkivskyi", on Pasichna Street"), detailed plans of which are agreed in the Department of Architecture and urban planning of Ivano-Frankivsk in the period 2016-2020 [2]. The comparative analysis of these objects is carried out according to the system of socio-mental indicators of comfort, which are characterized by the corresponding indicators of urban development [19]. Given the relatively stable environmental situation in the city of Ivano-Frankivsk, the level of service quality of residential complexes and real estate prices, safety requirements for these architectural objects are provided relatively equally. Undoubtedly, the number of expert assessments of this object can prove this. At the same time, the only criterion for selecting these objects is only the place of construction - the territory of Ivano-Frankivsk.

This will test the hypothesis of the universality of the application of integrated analysis and evaluation of multi-storey residential complexes. Assessment of meeting the needs of people (Table 1) in residential complexes was carried out on a rating scale "1-3", which corresponds to the following parameters:

- 1 - the needs of people do not have an architectural and town-planning solution in the studied object or architectural techniques used in this object do not meet this human need;

- 2 - architectural and planning solutions of the studied residential complex partially meet the needs of people;

- 3 - architectural and planning solutions of the studied residential complex fully meet the needs of people.

Undoubtedly, this assessment is quite conditional for quality indicators (level of comfort depending on the number of floors, etc.), but in this study the main task is to characterize the tools of analysis of housing complexes in accordance with social needs and highlight its features. Using the method expert assessments (the condition for choosing an expert was the presence of a qualification certificate of the chief architect of the project and practical activities in the field of residential architecture) [4].

According to the results of the analysis (Fig. 2, Fig. 3, Fig. 4) and assessment of the compliance of people's needs for comfort in the presented samples of housing construction, it was determined that the residential complex "Klubne Mistechko 12" on Promyslova street in IvanoFrankivsk has the highest total score -54 points. 
Comprehensive analysis of the residential quarter "Klubne Mistechko 12" in Ivano-Frankivsk

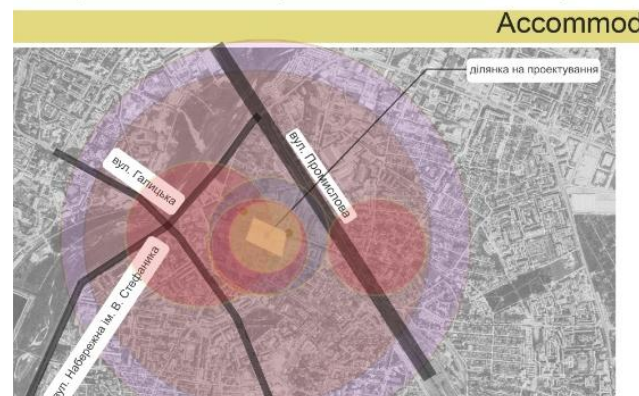

Availability of good transport links

Availability of recreational areas

Good view from the window

Proximity to public transport stops

Social infrastructure

Availability of educational institutions

Recreational accessibility area Coverage of all areas of the city Transport connection

Recreational accessibility area Coverage area of educational institutions

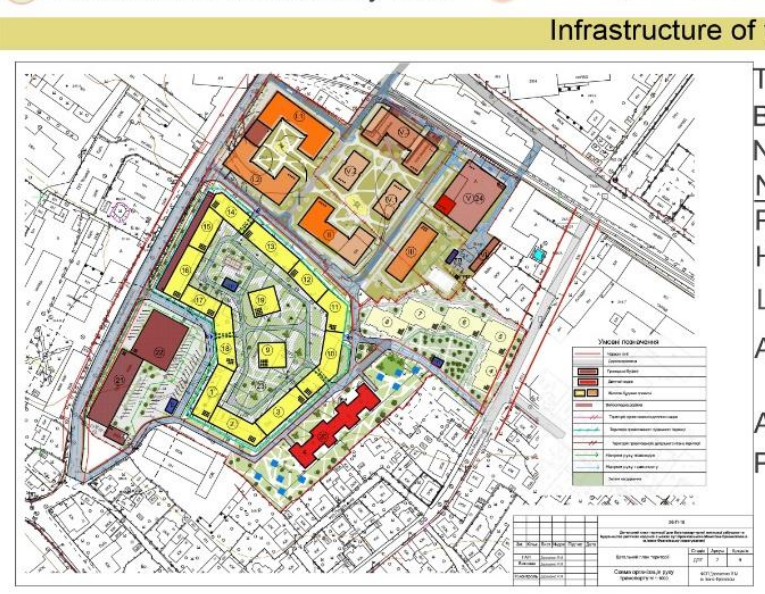

The area of the plot is $\quad-76100$ sq.m.

Building area $\quad-19571$ sq.m.

Number of population - 3400-3700 people

Number of apartments -1573

Population density $\quad-430-450$ persons / ha

Housing provision $\quad-27,5-32,0$ sq.m./person

Level of greening $\quad-45 \%$

Attractiveness of courtyards

Availability of large areas of the courtyard

Provision of parking spaces $-0,44$ p.s/ ap

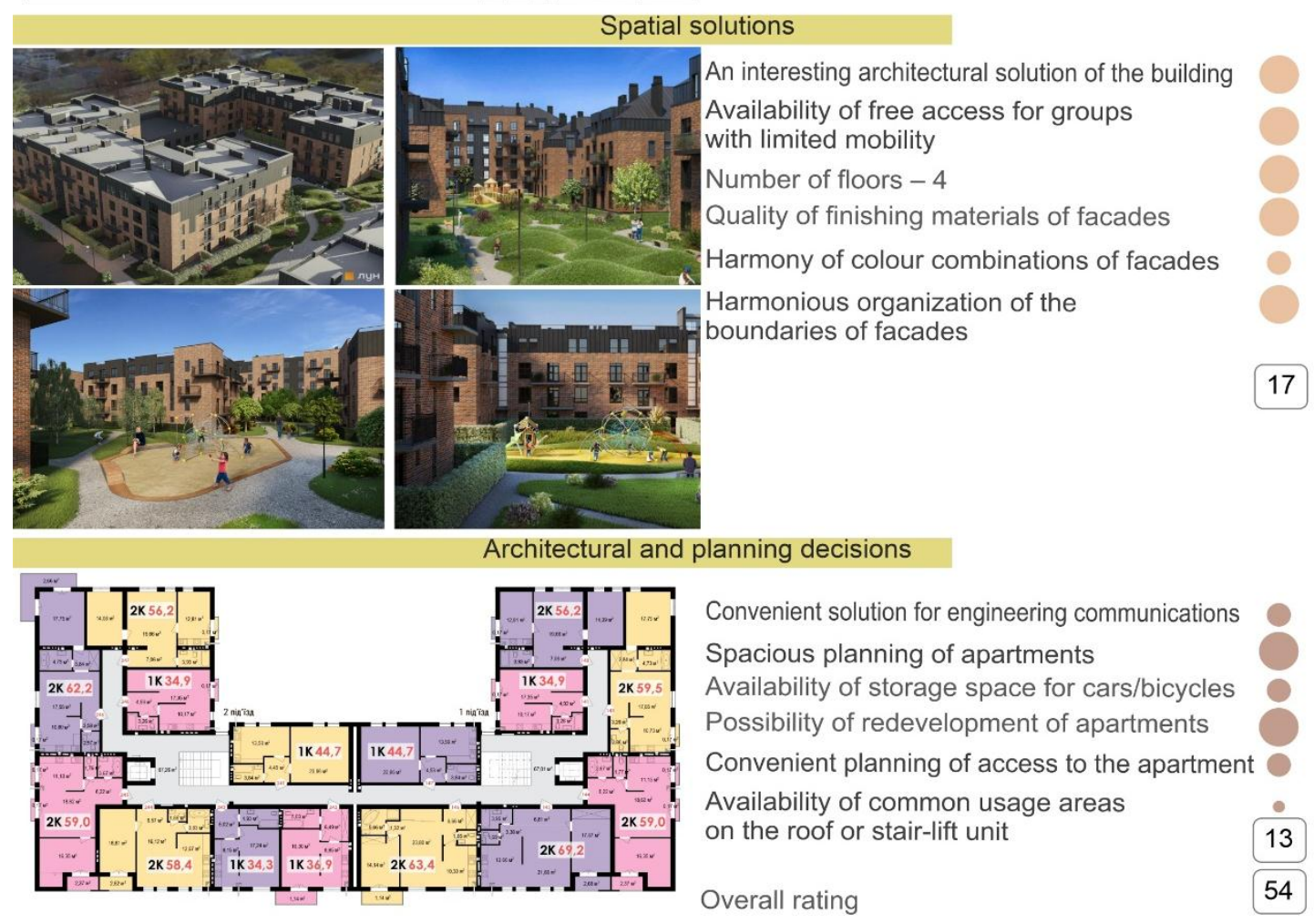

Fig. 2. Analysis of the comfort of the residential complex "Klubne Mistechko 12", Ivano-Frankivsk, Ukraine 
Comprehensive analysis of the residential quarter "Kvartal Videnskyi" in Ivano-Frankivsk

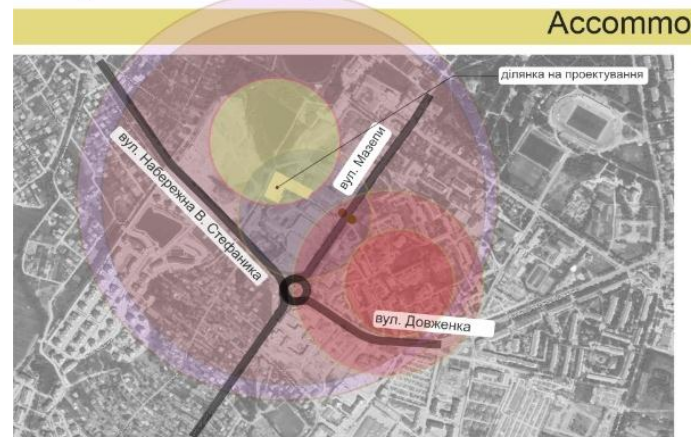

Availability of good transport links

Availability of recreational areas

Good view from the window

Proximity to public transport stops

Social infrastructure

Availability of educational institutions

Recreational accessibility area

Coverage of all areas of the city

Transport connection

Recreational accessibility area

Coverage area of educational institutions

Infrastructure of yard territories

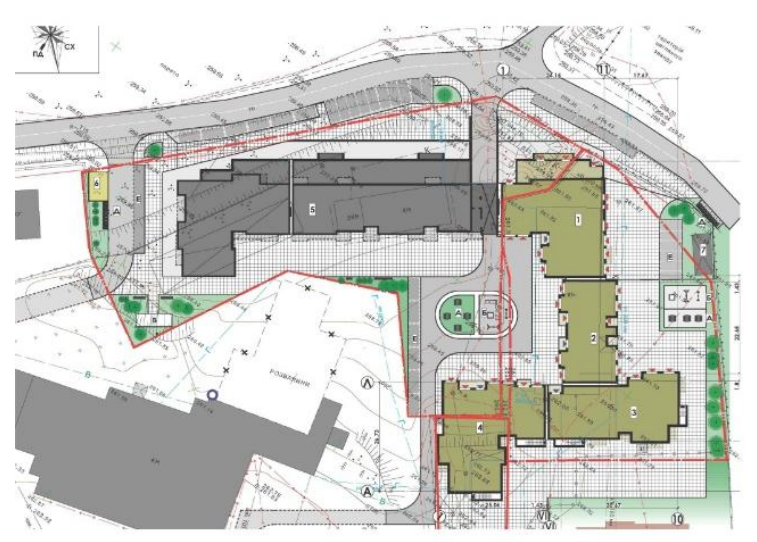

The area of the plot is -26700 sq.m.

Building area - 6400 sq.m.

Number of population - 1824 people

Number of apartments - 288

Population density - 450 persons / ha

Housing provision - 14,6-16 sq.m./ person

Level of greening - 39,4\%

Attractiveness of courtyards

Availability of large areas of the courtyard

Provision of parking spaces- 0,31 p.s./ ap.
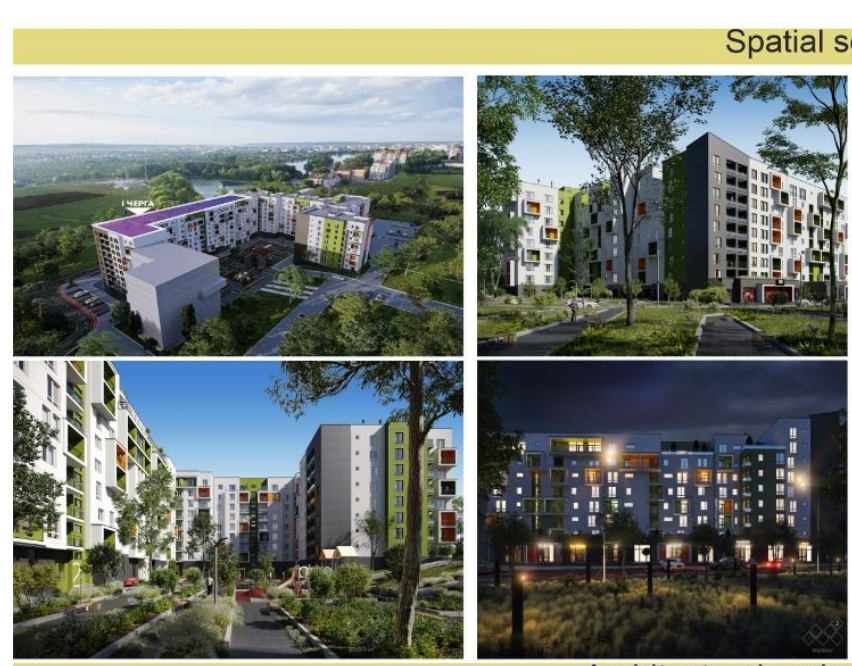

Spatial solutions

Architectural and planning decisions

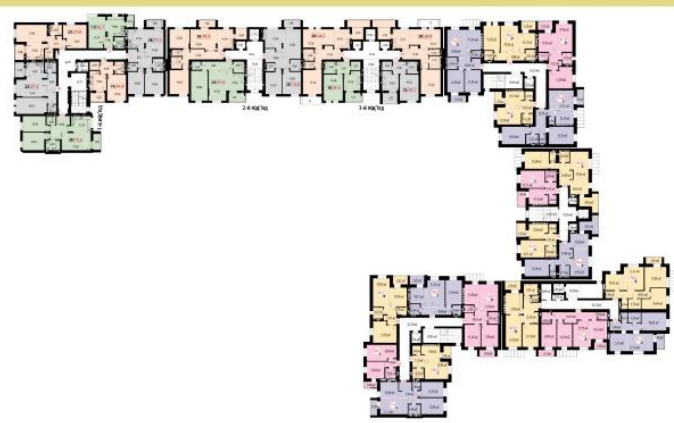

Convenient solution for engineering communications
Spacious planning of apartments
Availability of storage space for cars/bicycles
Possibility of redevelopment of apartments
Convenient planning of access to the apartment
Availability of common usage areas
on the roof or stair-lift unit
Overall rating

Fig. 3. Analysis of the comfort of the residential complex "Kvartal Videnskyi", Ivano-Frankivsk, Ukraine 
Comprehensive analysis of the residential quarter "Kvartal Lemkivskyi" in Ivano-Frankivsk

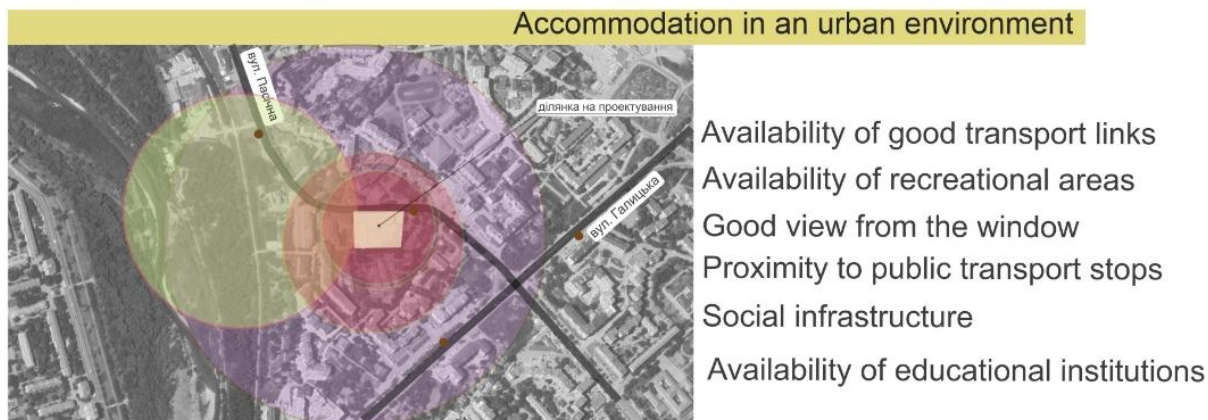

Recreational accessibility area Coverage of all areas of the city Transport connection

Recreational accessibility area

Coverage area of educational institutions
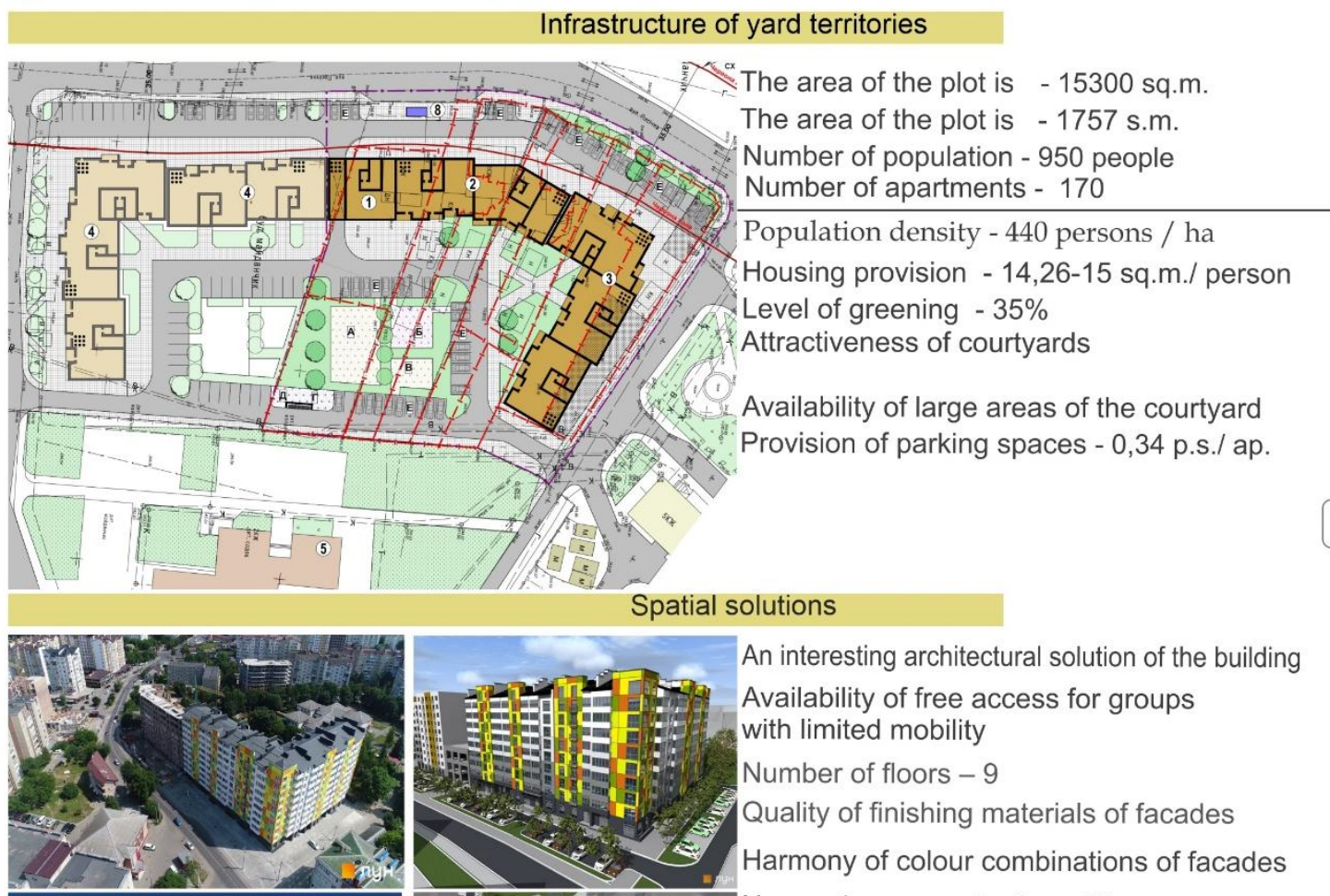

Spatial solutions
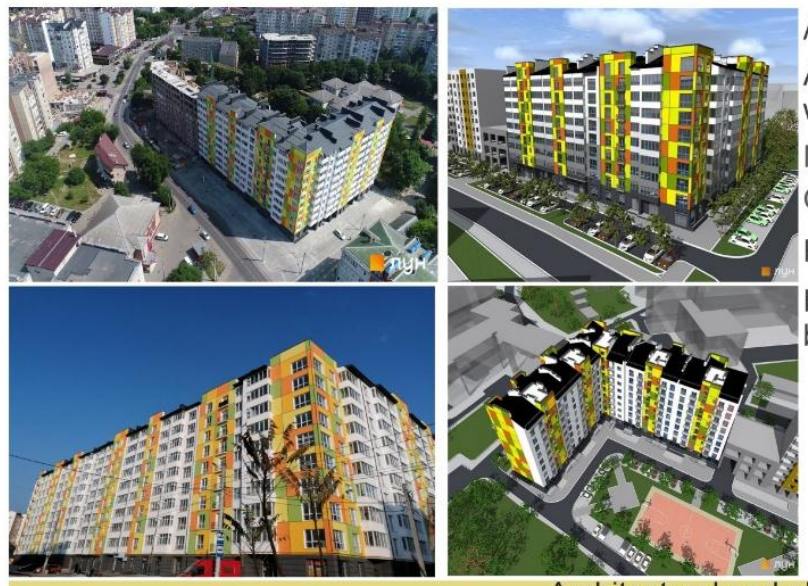

An interesting architectural solution of the building

Availability of free access for groups

with limited mobility

Number of floors -9

Quality of finishing materials of facades

Harmony of colour combinations of facades

Harmonious organization of the

boundaries of facades

\section{Architectural and planning decisions}

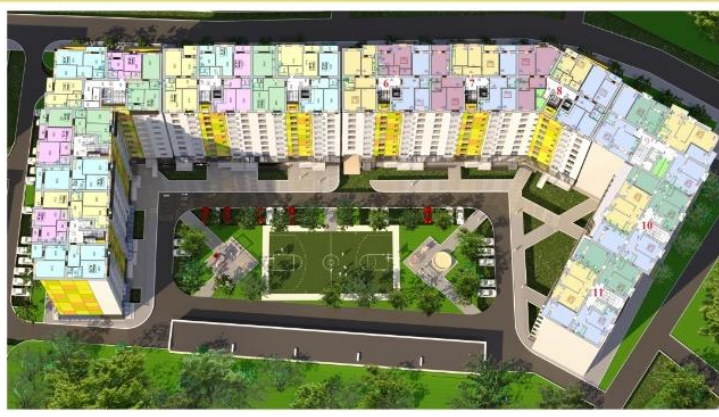

Convenient solution for engineering communications

Spacious planning of apartments

Availability of storage space for cars/bicycles

Possibility of redevelopment of apartments

Convenient planning of access to the apartment

Availability of common usage areas

on the roof or stair-lift unit

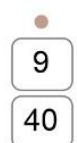

Fig. 4. Analysis of the comfort of the residential complex "Kvartal Videnskyi", Ivano-Frankivsk, Ukraine 
However, further analysis of 3 samples of the studied residential complexes shows the heterogeneity of assessment at different architectural and planning levels. For example, the total score of the residential complex "Klubne Mistechko 12" at the level of accommodation in the urban environment is -11 points, which is the lowest score among the analyzed sample. Applying the method of distance to the ideal, the model of the field of assessments of the comfort of the residential complex is formed in accordance with 4 evaluation criteria at the level of urban planning, formation of the master plan, spatial solution and planning organization of residential sections (Fig.5).

Analysis of the Residential quarter "Klubne Mistechko 12", Ivano-Frankivsk

\section{Analysis of the Residential quarter "Lemkivskyi", Ivano-Frankivsk}

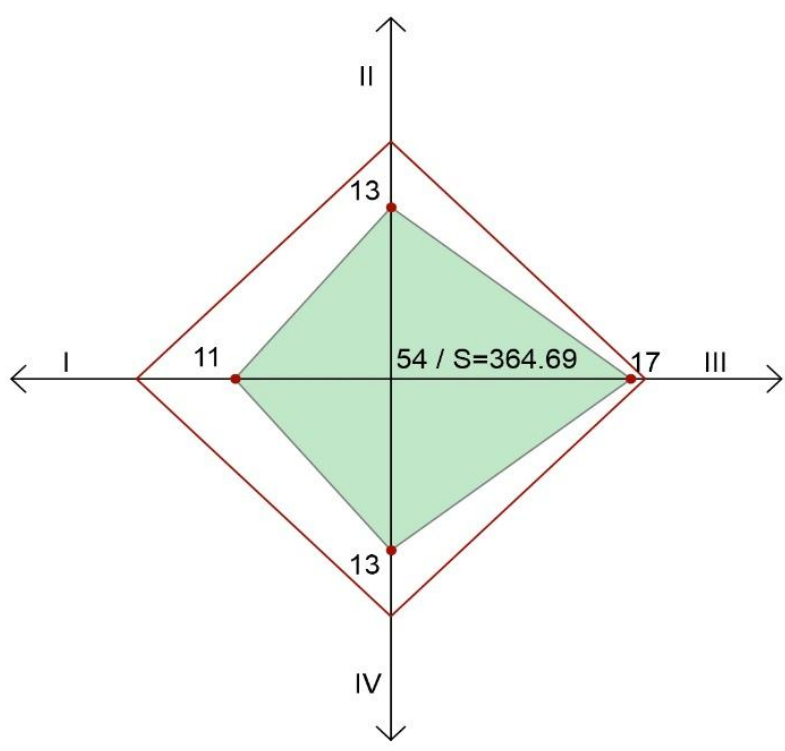

Analysis of the Residential quarter "Videnskyi", Ivano-Frankivsk

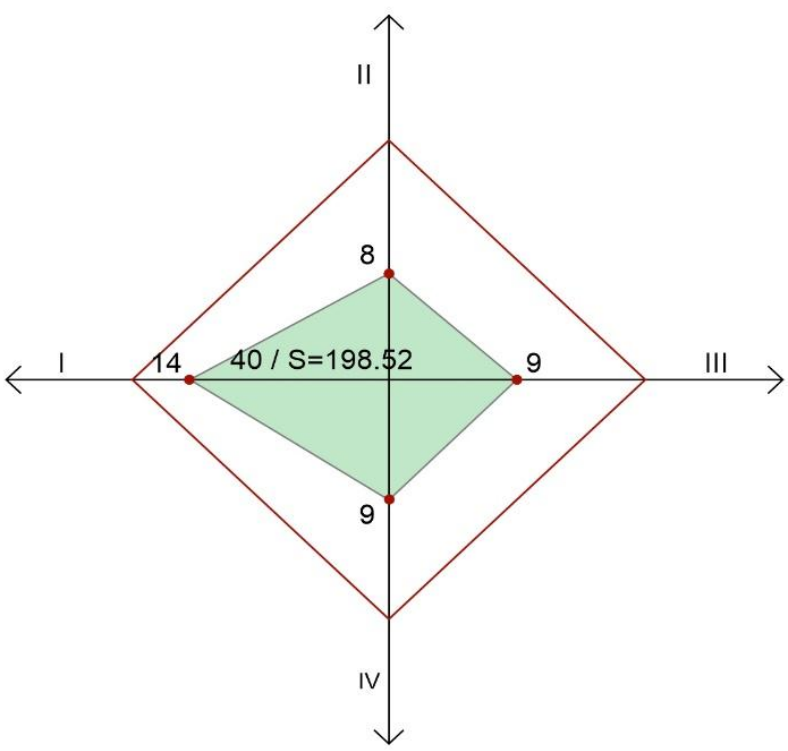

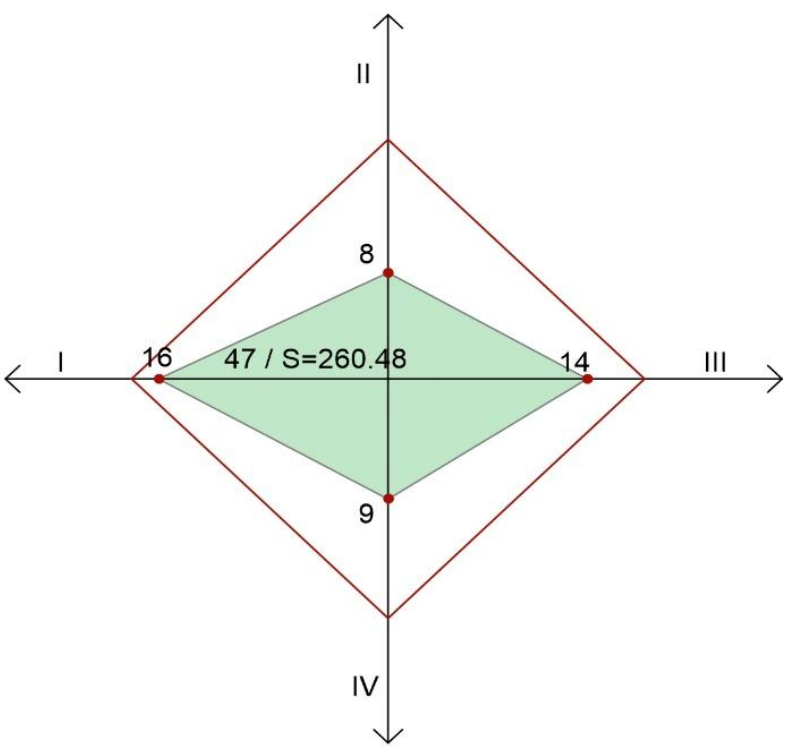

I-location in an urban environment II- infrastructure of yard territories III- three-dimensional solutions IV - architectural and planning decisions

- maximum project evaluation - actual project evaluation

Fig. 5. Assessment of the comfort of the residential area in the system of models "assessment field"

The actual estimates of the analysis of residential complexes are given in comparison with the idealized limit of the maximum estimates of the project, which more clearly demonstrates the criterion of comfort on different levels of architectural and spatial development. 
This study is formed by 4 vector criteria, respectively, the evaluation field has the form of an equilateral quadrilateral. The area of the idealized variant with the maximum evaluation indicators is 18 points for each of the levels of the study. Accordingly, the area of the polygon describing the idealized variant is 648 sq. units. Areas of the criterion for assessing the comfort of residential complexes by the method of distances to the ideal are:

- residential quarter "Klubne Mistechko 12" - 364.69 sq. units;

- residential quarter "Videnskyi" - 260.48 sq. units;

- residential quarter "Lemkivskyi"- 198.52 sq. units.

Thus, the residential district "Clubne Mistechko 12" has the highest comfort rates among the studied objects. Analysis of different variations in the assessment of an architectural object at the stage of pre-design or design analysis allows you to form alternative concepts or improve the existing parameters of comfort by architectural means. To do this, situational variations of assessment field models have been developed in which each of the architectural and planning levels has low assessment indicators (Table 2). Analysis of the survey results [21] allows forming a "picture" of socio-psychological factors of living in residential complexes with low scores at each architectural and spatial level. These factors are socio-mental factors of living in these conditions [15] (Table 2). Based on the analysis of variable types of the "assessment field" model of the residential quarter and socio-mental factors of living in these conditions, architectural and spatial means of balancing low comfort indicators at each of the assessment levels are formed.

Summary and Conclusion. The results of the sociological survey confirm the hypothesis that the structure of human socio-mental needs bring forward to the living environment is embedded in the general structure of human needs put forward by A. Maslow [5]. The primary link of this stratification is security needs, which include the quality of construction, decoration, engineering communications and environmental performance. However, in contrast to the group of parameters that are normalized in building codes, there is a whole group of socio-psychological aspects that form the criteria for the comfort of the living environment. The human needs assessment used in this study takes into account the needs of residents for medium and multi-story residential complexes. For the private housing sector, there is a different system of human needs, which must take into account the socio-mental and socio-economic component of potential residents of private homes. This refutes the hypothesis of the universality of the application of this evaluation system to all types of residential buildings.

A comparative analysis and assessment of socio-psychological aspects of comfort, implemented in multi-story residential complexes in Ivano-Frankivsk. The application of the method of expert assessments allows comparing and analyzing quantitative and qualitative indicators that form the criteria of socio-psychological comfort of residential complexes. The highest criterion was the residential district "Club Town 12" on Promyslov street in IvanoFrankivsk. Applying the method of "approach to the goal" allowed obtaining an assessment of the living environment at 4 levels of development of the living environment. The possibility of comparing equivalent generalized criteria of different architectural objects partially confirms the hypothesis of universality of this algorithm of analysis and evaluation.

In the process of creating the project, the architects have limited tools to change the conditions of housing in the urban environment using the materials of urban planning documentation (master plans and spatial development plan). At low rates of assessment of conditions location of the site for the residential complex, there is a need to create a quality transport and pedestrian infrastructure within the given design object and the relative autonomy of the functions of social services and recreation within the given quarter.

With low indicators of comfort of the residential complex at the level of infrastructure of inter-house and indoor areas, a system of alternative variations of greening should be formed (creation of a house-garden, use of vertical greening, etc.). Low rates of assessment of spatial planning decisions of multi-story residential buildings indicate the need to increase energy efficiency of housing, arrangement of operated terraces and recreation areas on the roofs of buildings, creation of communication zones, common areas between residents of each residential

Bulletin of Odessa State Academy of Civil Engineering and Architecture, 2021, no. 84, page 16-31 
building. Low indicators of assessment of architectural and planning decisions of apartment buildings indicate the need to increase public service areas and variability of planning decisions of housing, as well as increase the level of greening of adjacent areas.

Table 2 - Variable models of the assessment field of residential complexes in the system of urban environment and the system of their balancing by architectural techniques

\begin{tabular}{|c|c|c|}
\hline $\begin{array}{l}\text { Variants of the main types of } \\
\text { the "assessment field" model of } \\
\text { the residential quarter }\end{array}$ & $\begin{array}{l}\text { Socio-mental factors of living } \\
\text { in these conditions }\end{array}$ & $\begin{array}{c}\text { Architectural and planning } \\
\text { means of balancing this } \\
\text { aspect }\end{array}$ \\
\hline \multirow[t]{5}{*}{$\begin{array}{l}\text { Low rates of assessment of the } \\
\text { location of the neighborhood in } \\
\text { the urban environment }\end{array}$} & - proximity to the workplace & $\begin{array}{l}\text { - the need for bicycle } \\
\text { infrastructure in the yard; } \\
\text { - arrangement of bicycle } \\
\text { storage places directly in } \\
\text { buildings; } \\
\text { - availability of a sufficient } \\
\text { level of parking spaces in } \\
\text { parking lots. }\end{array}$ \\
\hline & $\begin{array}{l}\text { - active development of this } \\
\text { area of the city }\end{array}$ & $\begin{array}{l}\text { - ensuring a quality level of } \\
\text { social infrastructure by } \\
\text { increasing commercial space } \\
\text { on the first floors of the quarter }\end{array}$ \\
\hline & - the priority of a quiet life & $\begin{array}{l}\text { - orientation of residential } \\
\text { sections relative to the main } \\
\text { highways; } \\
\text { - arrangement of active } \\
\text { recreation areas equidistant } \\
\text { from the windows of } \\
\text { residential sections }\end{array}$ \\
\hline & $\begin{array}{l}\text { - temporary housing with } \\
\text { subsequent change }\end{array}$ & $\begin{array}{l}\text { - open planning with } \\
\text { redevelopment opportunities }\end{array}$ \\
\hline & - features of a way of life & $\begin{array}{l}\text { - formation of a wide range of } \\
\text { multifunctional public } \\
\text { premises on the ground floors }\end{array}$ \\
\hline \multirow[t]{3}{*}{$\begin{array}{l}\text { Low indicators of assessment of } \\
\text { infrastructure of inter-house and } \\
\text { courtyard }\end{array}$} & $\begin{array}{l}\text { - features of a way of life with } \\
\text { fragmentary stay in housing } \\
\text { (less than } 12 \text { hours a day) }\end{array}$ & $\begin{array}{l}\text { - increasing landscaping of the } \\
\text { residential area by alternative } \\
\text { methods of greening (green } \\
\text { gardens, vertical greening); } \\
\text { - change of the image of the } \\
\text { building formation of green } \\
\text { buildings-gardens }\end{array}$ \\
\hline & $\begin{array}{l}\text { - priority of town-planning } \\
\text { conditions of placement of the } \\
\text { residential district over intra- } \\
\text { quarter building }\end{array}$ & $\begin{array}{l}\text { - arrangement of additional } \\
\text { recreation areas directly in the } \\
\text { residential house }\end{array}$ \\
\hline & $\begin{array}{l}\text { - features of psychological } \\
\text { behavior (introvert) }\end{array}$ & $\begin{array}{l}\text { - arrangement of green } \\
\text { terraces, internal atriums, light } \\
\text { mines }\end{array}$ \\
\hline
\end{tabular}


Continuation of Table 2

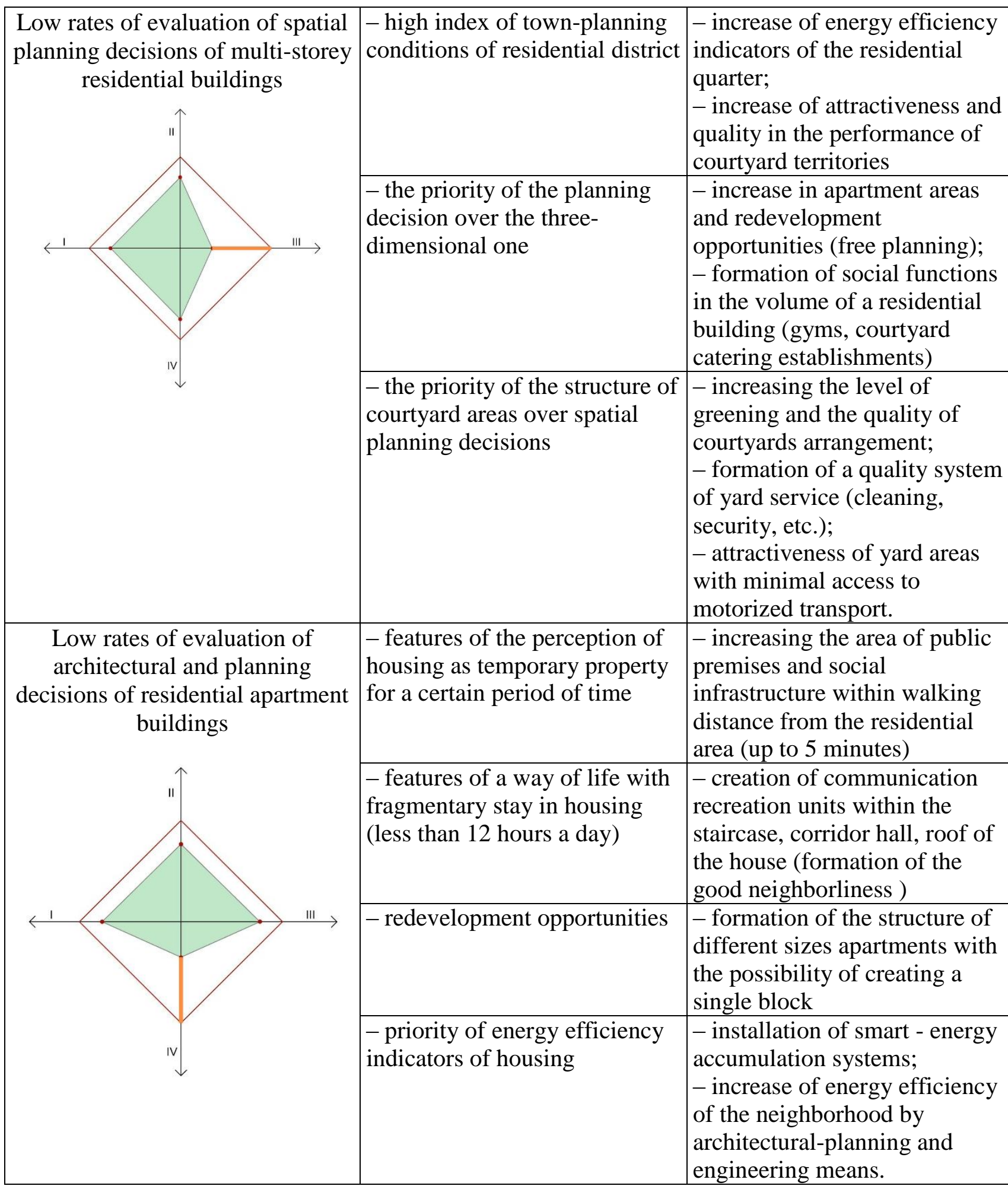

\section{References}

[1] M. Adelino, A. Scholar, F. Severino, "House prices, collateral, and self-employment", Journal of financial Economics, 117, pp. 288-306, 2015.

[2] Architecture Management, design and Urban Planning Activity Ivano-Frankivsk City Council, 2020. Detail plans of territories. Available: https://dma.if.ua/home/department/city-building-documentation/detailed-plans/ Accessed on: 15 Jan, 2021. 
[3] H. Armstrong, C. Boonstra, E. Cullinan, B. Derbyshire, B. Edwards, A. Grant, D. Howarth, D. Lock, G. Mills, P.-F. Smith, D. Taylor, D. Turrent, A. Wright, Sustainable Housing: principles and practice. E, FN Spon, USA, Canada, ISBN: 0-419-24620, 2005.

[4] H. Bouttaba, M. Mili, W. Hamma, S.-D. Bouttaba, "Spatial logic of the neo-rural houses of the Msilien Guebla in Algeria", Urbanism. Architecture. Constructions, 11(1), pp. 33$56,2020$.

[5] V. Dung Le, "Micro-culture and Macro-culture in urban housing architecture", ESCI, MATEC Web of Conferences, Portugal, p.12-14, 2018.

[6] M. Dyomin, T. Marshal, M. Habrel, "Metropolies of Lodzy and Lviv: features of formation and development", Modern problems of architecture and urban planning, 56, pp. 174-203, 2020.

[7] M. Gabrel, O. Morklyanyk, "Some problems of estimating unique architectural monuments based on the method of "distance to ideal", Bulletin of the National University "Lviv Polytechnic", 757, pp. 7-10, 2013.

[8] J. Gehl, Cities for People. Island Press, Washington DC, USA, ISBN: 978-1597265737, pp. 156-162, 2010.

[9] R. Gifford, "The Consequences of Living in High-Rise Buildings", Architectural Science Review, 50(1), pp. 35-38, 2007.

[10] M. Janpourtaher, "A scientific approach of preservation treatment and restoration procedures on historical royal Songket Sarong", International Journal of Conservation Science, 10(1), pp. 69-80, 2019.

[11] S. Joss, "Eco-Cities: The Mainstreaming of Urban Sustainability-Key Characteristics and Driving Factors", International Journal of Sustainable Development and Planning, 6(3), pp. 268-281, 2011.

[12] V. Kalashnikova, "Comfortable housing. Classification of housing in dependence from the level of comfort. Features of elite housing design", Young Scientist, 8(23), pp. 23-27, 2015.

[13] A. Lasiewicz-Sych, "What matters in housing architecture - a survey of dwellers' opinions, WMCAUS", IOP Conf. Series: Materials Science and Engineering, Prague, Czech Republic, p. 46, 2019.

[14] G. Litoshenko, "Standadization and assessment of housing comfort", abstract of the dissertation for the degree candidate of architecture, KNUBA, Kyiv, Ukraine, pp. 42-65, 2004.

[15] F. Likitswat, "Future Cities: New Generation's Visions of Sustainability Concepts and Models", Future Cities and Environment, 5(1), pp.1-8, 2019.

[16] O. Luka, F. Gaman, C. Iacoboaea, F. Petrescu, M. Aldea, "Main challenges of residential areas", Urbanism. Architecture. Constructions, 8(2), pp. 119-128, 2017.

[17] B. Phillips, G. Sjoberg, R. Nett, "A Methodology for Social Research", American Sociological Review, 34(4), pp. 566-567, 1969.

[18] F. Rodney, "Social Constructionism and Housing Studies: A Critical Reflection", Urban Policy and Research, 26(2), pp.159-175, 2008.

[19] SBC B. 2.2-12:2019, [online] 2019. Planning and development of territories. Department of Regional Development of Ukraine. Available: https://dbn.co.ua/load/normativy/dbn/b_2_2_12/1-1-0-1802. Accessed: 10 December, 2020.

[20] SBC B. 2.2-15:2019, [online] 2019. Residential building. Substantive, Department of Regional Development of Ukraine, Available: https://dbn.co.ua/load/normativy/dbn/dbn_v_2_2_15_2015_zhitlovi_budinki_osnovni_po lozhennja/1-1-0-1184. Accessed: 10 December, 2020.

[21] I. Smadych, Aspects that are most important for you when choosing / comparing multiapartment housing for the place of residence. Sociological survey, Ivano-Frankivsk, Ukraine. [online] 2020. Available: https://drive.google.com/drive/folders/19hh12KNzbjO-ptveEhsNvVQkMl6XbXa?usp=sharing. Accessed 12 Dec. 2020. 
[22] A. Stoa, "What Buildings do: The Potential Role or Architecture in Housing for Disadvantaged Residents in Norway", New Norwegian Architecture: Progression and Confusion, 6(1), pp. 24-29, 2017.

[23] B. Stoiljkovic, N. Petkovic-Grozdanovic, G. Jovanovic, "Individualization Concept in Housing architecture", Fasta Universitatis: Architecture and Civil Engineering, 13(3), pp. 207-218, 2015.

[24] B. Stoneham, D. Smith, The house and the home: The balance of architecture and psychology within the residential home. Deakin University, Geelong, Australia, 2015.

[25] M. Vilenskii, O. Smirnova, "Methodology for evaluating the websites of the authorities responsible for urban planning", Urbanism. Architecture. Constructions, 11(1), pp. 5-16, 2020 .

[26] N. Winston, M. Eastaway, "Sustainable Housing In The Urban Context: International Sustainable Development Indicator Sets And Housing", Social Indicators Research, 87(2), pp. 211-221, 2008.

[27] M. Zivkovic, G. Jovanovic, "A method for evaluating the degree of housing unit flexibility in multi-family housing", Facta Universitatis, Series: Architecture and Civil Engineering, 10(1), pp. 17-32, 2012.

\title{
АНАЛИЗ И ОЦЕНКА КОМФОРТА ЖИЛИЩНЫХ КОМПЛЕКСОВ (ИССЛЕДОВАНИЯ РАЗВИТИЯ ЗАПАДНОЙ УКРАИНЫ)
}

\author{
Смадич И.П., к.арх. доцент, \\ Architectvan@gmail.com, ORCID: 0000-0001-7964-5730 \\ Ивано-Франковский национальный технический университет нефти и газа \\ ул. Карпатская, 15, г. Ивано-Франковск, 76019, Украина
}

\begin{abstract}
Аннотация. Архитекторы и градостроители в процессе проектирования жилых районов используют строительные нормы и правила, которые рассматривают комфорт проживания только с точки зрения безопасности, санитарии и экологических показателей. В статье освещена проблема учета ряда дополнительных социальных параметров комфортности, влияющих на характеристики комфортности проживания. Структура комплексного анализа жилья формируется путем оценки элементов комфортности проживания. Представленный алгоритм исследования включает последовательное использование методов социологического опроса, оценки и моделирования. Выявив социально-психологические факторы комфортности микрорайона на разных уровнях градостроительной оценки (в разрезе расположения в системе города, формирования окружающей территории, пространственного и архитектурно-планировочного уровня), 3 проекта жилой застройки Ивано-Франковска. Для сравнительного анализа использованы архитектурно-планировочные решения жилых кварталов «Лемкивский», «Клубный городок 12», «Виденский» строительство которых началось в период с 2017 года.

При этом учитывались не только количественные технико-экономические показатели отдельных элементов проекта, но и качественные показатели, измерение которых в нормальных условиях является ресурсоемким процессом. В результате анализа и проведенной оценки формируется графическая модель комплексного анализа жилого квартала, что позволяет проводить сравнение различных проектных решений независимо от размера участка, количества жилых секций и т.д. Используя метод движение до идеала, проведен комплексный анализ разных жилых комплексов. Полученные результаты позволяют как на этапе проектирования жилых кварталов, так и при анализе эксплуатируемых объектов оценивать их в соответствии с потребностями людей, а также уравновешивать показатели комфортности, применяя предложенные архитектурнопланировочные приемы.
\end{abstract}


Ключевые слова: социопсихологический комфорт многоэтажных жилых комплексов, оценка социопсихологического комфорта, метод движения до идеала.

\title{
АНАЛІЗ ТА ОЦІНКА КОМФОРТУ ЖИТЛОВИХ КОМПЛЕКСІВ (ДОСЛІДЖЕННЯ РОЗВИТКУ ЗАХІДНОЇ УКРАЇНИ)
}

\author{
Смадич I.П., к.арх. доцент, \\ Architectvan@gmail.com, ORCID: 0000-0001-7964-5730 \\ Івано-Франківський національний технічний університет нафти і газу \\ вул. Карпатська, 15, м. Івано-Франківськ, 76019, Україна
}

\begin{abstract}
Анотація. Архітектори та градобудівники у процесі проектування жилих районів використовують будівельні норми та правила, які розглядають комфортне проживання лише 3 точки зору безпеки, санітарії та екологічних показників. У статті оновлюється проблема навчання, що включає додаткові соціальні параметри комфортності, що впливають на характеристики комфортності проживання. Структура комплексного аналізу житла формується шляхом оцінки елементів комфортності проживання. Представлений алгоритм дослідження включає наступне використання методів соціологічного опитування, оцінки та моделювання. Виявив соціально-психологічні фактори комфортності мікрорайону на різних рівнях градобудівельної оцінки (у розрізі розташування в системі міста, формуванні навколишньої території, просторового та архітектурно-планувального рівня), 3 проекти жилої забудови Івано-Франківська. Для порівняльного аналізу використовувалися архітектурно-планувальні рішення живих кварталів «Лемківський», «Клубний городок 12», «Віденський» будівництво яких розпочалося в період з 2017 року.

При цьому враховувались не тільки кількісні техніко-економічні показники окремих елементів проекту, але й якісні показники, оцінка яких у нормальних умовах є ресурсоємким процесом. У результаті аналізу та перевіреної оцінки формується графічна модель комплексного аналізу живого кварталу, що дозволяє проводити порівняння різних проектних рішень незалежно від розміру учасників, кількості живих секцій, тощо. Використовуючи метод руху до ідеалу, проведено комплексний аналіз різних живих комплексів. Наведені результати дозволяють як на етапі проектування живих кварталів, так і при аналізі експлуатованих об'єктів, оцінювати їх відповідно до потреб людей, а також врівноважувати показники комфортності, застосувавши запропоновані архітектурно-планувальні проекти.

Ключові слова: соціопсихологічний комфорт багатоповерхових житлових комплексів, оцінка соціопсихологічного комфорту житлових комплексів, метод руху до ідеалу.
\end{abstract}

Стаття надійшла до редакції 25.05.2021

Bulletin of Odessa State Academy of Civil Engineering and Architecture, 2021, no. 84, page 16-31 